\title{
Development of chemical practice guides class xi project based to improve student's chemical learning outcomes on acid base materials
}

\author{
Bajoka Nainggolan*, Ita Sri Apika Pinem, Wesly Hutabarat \\ Department of Chemistry, Universitas Negeri Medan, Medan 20221, Indonesia
}

\begin{abstract}
:
This study aims to obtain a standard project-based laboratory chemistry guide for class $\mathrm{XI}$ students of Second semester on acid base material. The sample consists of 3 tutorial guide publisher A, B, and C, 2 teacher of senior high school (SMA) 4 Medan, 2 Unimed chemistry lecturer and 2 class XI SMA 4 Medan. Research is descriptive and experimental development with ADDIE models. The results show that the guides have been developed and the standards are in accordance National Education Standards Agency (BSNP). Result validation practice guides developed get the average score of 3.48 times higher than the standard practicum guide $\mathrm{A}=3.18, \mathrm{~B}=3.32$; and $\mathrm{C}=30.75$. Experimental practice test improves the average learning outcomes of experimental class 1 (using development guide) $70.8 \%$ and experiment 2 (using textbook) 54.1\%. Psychomotoric and affective grade experiment class 1 higher than the experimental class 2 . The resultant learning improvement data was analyzed by right $t$ test. Test of $t$-test for learning result obtained $\mathrm{t}$ count and table, 6.68 and 1.678 , respectively, at level 0.05 . This indicates that the project-based practice guide has been well developed and feasible for chemical learning in senior high school.
\end{abstract}

Keywords:

acid base material; development; laboratory guide; project based learning

\section{Introduction}

Chemistry is one of the subjects in Senior High School (SMA) taught through scientific method. If examined from the nature of science, chemistry is experimental science means that in learning chemistry is not enough just to hear and read it, but it is necessary to do learning activities such as lab work that will help build student knowledge about the material being studied (Addin et al., 2014). In general practicum activity is the performance shown by teacher or student in form of demonstration and experiment by students who continuously in laboratory through experiment or project (Yance et al., 2013).

Obstacles experienced by teachers in the implementation of labs in schools, such as the lack of availability practical chemistry guide that can lead students when practicum (Tuysuz, 2010). From the observation of researchers through observation in SMAN 4 Medan that there are some things that become problems in the learning

\footnotetext{
* Corresponding author.

nainggolanbajoka@gmail.com

doi: https://doi.org/10.24114/jpkim.v10i2.11018
}

process of chemistry, that is (1) the absence of guidance of chemistry practicum in the school, and (2) chemical practicum conducted only on the sheet of practicum activity in text book and student worksheet (LKS) owned by students.

Considering the importance of practical guidance in the implementation of practicum activities, it is necessary to develop an integrated chemistry practicum guide with learning that meets the eligibility criteria according to National Education Standards Agency (BSNP) standards for high school students of nature (Zulaiha et al., 2014). One of the learning strategies considered to change the abilities of chemistry is project based learning or project-based learning (Ulger, 2018). Learning-based learning gives students the opportunity to learn and work together to solve problems and then present the results of their work to the audience for presentation. Implementation of project-based learning will involve students in practical activities, thus demanding an active role of students to prove hypotheses and analyze them according to existing theories and can build their own understanding (Rose \& Prasetya, 2015), which imphasizes that 
learning is interdiciplinary, student centres, collaborative, and integrated with the real world (Chiang \& Lee, 2016). Project based learning $(\mathrm{PjBL})$ is a teaching method that involves students in learning. Students' interests, critical thinking skills, team-related skills and skills improved as they worked on PjBL activities (Sepahkar et al., 2015). Explained that project-based learning is a great opportunity for discussion for learners, working on the students' immediate discovery of real-world problems(Ellis \& Hafner, 2008).

So in this research will be conducted development of chemistry based project chemistry guide on acid-base material in accordance with BSNP standard, then tested to see the improvement of students' chemistry learning result by using guide of development result result and affective and psychomotor value of students. With an indicator that improvements in student learning outcomes practicing using a project-based practical guide will be higher than those not using.

\section{Materials and Methods}

Research was held in SMAN 4 Medan on acid base materials with ADDIE models, is analysis, design, development, implementation, and evaluation (Arkün \& Akkoyunlu, 2008). The sample of this research is 3 tutorial guide publisher A, B, and C, 2 teacher of SMAN 4, 2 unimed chemistry lecturer and 2 class XI SMAN 4 Medan. Class XI IPA 5 as experimental class 1 was given practice treatment using a project based practical guide, while class XI IPA 2 as experimental class 2 was given practice treatment using student's handbook. Some of processes in this research are analyzing chemical practical guide, designing practical guide, developing practical guide, implementation practical guide and evaluation and data analysis. The research procedure can be seen in Fig 1.

Data analysis techniques used to analyze data validation results from lecturers and teachers is an average technique. The formula used to calculate the data of questionnaires is calculated with the average calculation is:

$$
X=\frac{\Sigma X}{n}
$$

$\mathrm{X}=$ average; $\Sigma X=$ the number of validator's answer; $\mathrm{n}=$ the number of validator

A full range of validation criteria against calculations can be observed in Table 1.
Table 1

Criteria validation analysis average

\begin{tabular}{ll}
\hline Average & Validation Criteria \\
\hline $3.26-4.00$ & Very Valid \\
$2.51-3.25$ & Valid \\
$1.76-2.50$ & Less valid (revision) \\
$1.00-1.75$ & lnvalid (total revision) \\
\hline
\end{tabular}

Data analysis of experimental test results of project chemistry based on the aspects of knowledge, attitude, and skills. For the aspect of knowledge seen from the increase of gain and attitude and skill aspects using assessment rubric. Hypothesis test used is one party t test, the test is done when it has done the testing of normality and homogeneity of data (data gain). The formula used to calculate percent increase in student learning outcomes (gain) follows the method of Meltzer (2002), namely:

$$
\mathrm{g}=\frac{\text { post }- \text { test score }- \text { pre-test score }}{\text { maximumscore-pre-test score }}
$$

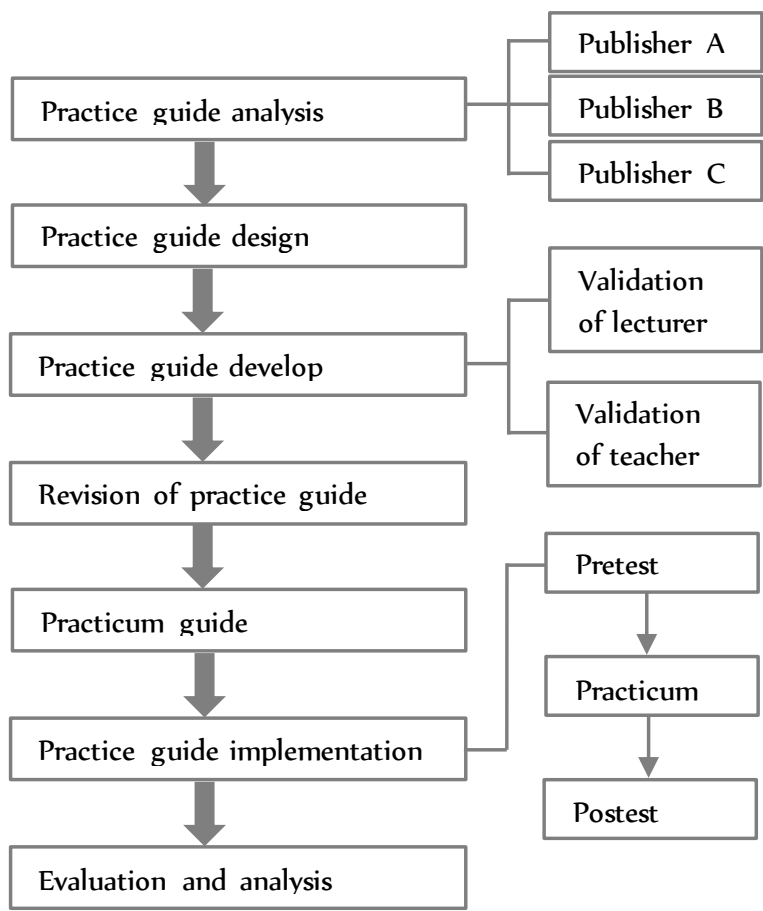

Fig 1. Procedure and addie steps development chemical practical guide class $\mathrm{XI}$ project bases on acid based materials (modified from Manalu et al., 2016).

\section{Results}

Analysis of the practicum guide $A, B, C$

A guide analysis of the $A, B$ and $C$ publisher practices on acid-base material according to BSNP is like Table 2. 
Table 2

Analysis result chemical practical guide.

\begin{tabular}{lccc}
\hline \multirow{2}{*}{ Standar BSNP } & \multicolumn{3}{c}{ Average of Pratice Guide } \\
\cline { 2 - 4 } & A & B & C \\
\hline Eligibility of content & 3.1 & 3.25 & 3.0 \\
Eligibility of language & 3.2 & 3.4 & 3.2 \\
Eligibility of presentation & 3.1 & 3.33 & 3.1 \\
Eligibility of graffiti & 3.33 & 3.33 & 3.0 \\
Average & 3.18 & 3.32 & 3.075 \\
\hline
\end{tabular}

The results of the analysis of the chemical practicum guide from publishers A, B, C, obtained some shortcomings such as not containing applications from material in daily life, not containing pictures of chemical equipment, not containing basic techniques and basic laboratory skills, design and practicum guide colors less attractive. Therefore, the development of the project-based chemical practicum guide was carried out.

\section{Validation of project-based practicum guides}

The average value of expert validators, namely 2 teachers and 2 lecturers on the validation of the chemical practicum guide developed for SMA class $\mathrm{XI}$ is as in table Table 3.

Table 3

Assesment of a practical guide on development.

\begin{tabular}{lccc}
\hline \multirow{2}{*}{ Standar BSNP } & \multicolumn{3}{c}{ Assesment of } \\
& practical guides \\
\cline { 2 - 4 } & $\begin{array}{c}\text { Lectu } \\
\text { rer }\end{array}$ & $\begin{array}{c}\text { Tea } \\
\text { cher }\end{array}$ & $\begin{array}{c}\text { Avara } \\
\text { ge }\end{array}$ \\
\hline Eligibility of content & 3.69 & 3.34 & 3.5 \\
Eligibility of language & 3.5 & 3.42 & 3.45 \\
Eligibility of presentation & 3.6 & 3.32 & 3.47 \\
Eligibility of graffiti & 3.67 & 3.33 & 3.5 \\
Total Average & 3.61 & 3.35 & 3.48 \\
\hline
\end{tabular}

The difference between the validator's assessment of the practical guide from the publishers A, B, C and the project-based practicum guide for development results can be seen as shown in Fig 2.

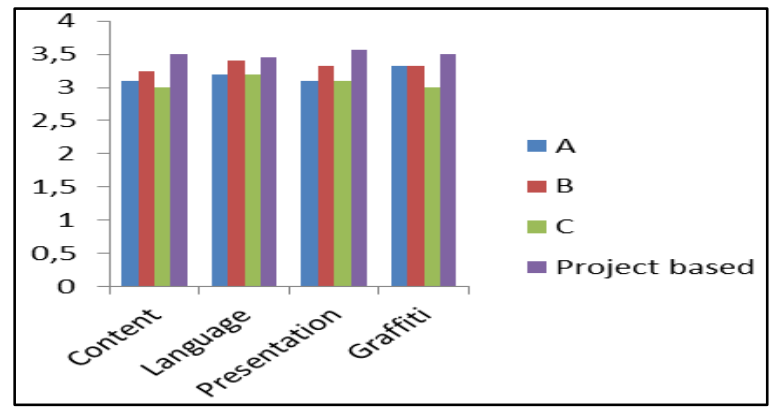

Fig 2. Diagram of differentiation of practical guides preparation.

\section{Psycomotoric assesment}

Psycomotororic grade of eksperimental class 1 is higher than experimental class 2 (82.74 > 79.91). Average of each psycomotoric Aspects like Fig 3.

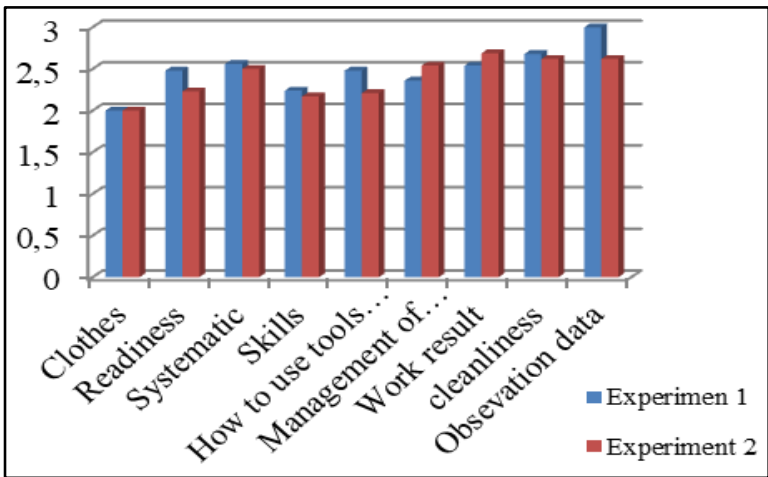

Fig 3. Average of each psycomotoric aspects.

\section{Affective assessment}

In affective assessment, it was found that the affective value of experimental class 1 was higher than the affective value of experimental class 2, namely $71.08>70.99$. The average of the affective values of each aspect can be seen as in Fig 4 . The average affective value of each aspect in the experimental class 1 and 2 .

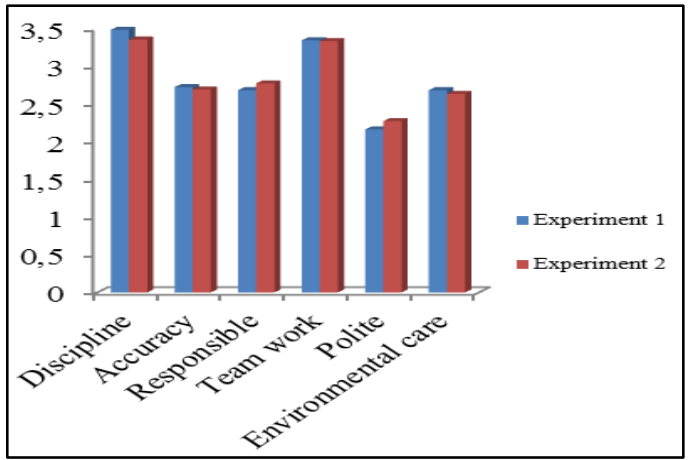

Fig 4. Average of each affective aspects.

\section{Discussion}

In accordance with the analysis of laboratory chemistry guidance, there are some drawbacks such as not loading the application of the material in daily life, not loading the drawing of chemical tools, not loading basic technique and basic laboratory skill, the design and color of the lab workbook is less interesting. Thus, a better development of project-based practice guides is made.

Hypothesis test is done after testing normality and homogeneity of data. Using the right-handed $t$ test formula is obtained tcount $>$ ttable (6.68> 
1.678) which means the accepted ( $\mathrm{Ha})$ hypothesis means that the implementation of the projectbased chemistry guide is better developed in improving students' chemical learning outcomes on acid-base material than the practicum of the student's handbook. The same thing has also been reported by Manalu et al. (2016).

lmprovement of student learning outcomes in acid-base material taught using a project-based practicum guide is higher than students taught using student handbooks. This is in line with research conducted by (Syamsu, 2018) that the use of practicum guides can guide students to develop creativity and scientific attitudes in conducting experiments. Gultekin (2007) reported that the application of $\mathrm{PjBL}$ can improve the quality of learning and improve student learning outcomes.

\section{Conclusion}

Based on the research results can be concluded that chemical practicum guide on acid-base material of development according to BSNP standard and improved learning outcomes with a chemistry lab guide based on a project that develops higher than the practicum of student books.

\section{Acknowledgments}

Thank you for the Directorate General of Higher Education for grants provided through the DRPM Project.

\section{References}

Addiin, I., Redjeki, T., \& Ariani, S.R.D. (2014). Penerapan model pembelajaran project based learning (PjBL) pada materi pokok larutan asam dan basa di kelas xi ipa 1 sma negeri 2 karanganyar tahun ajaran 2013/2014. Jurnal Pendidikan Kimia, 3(4), 7-16.

Arkün, S., \& Akkoyunlu, B. (2008). A Study on the development process of a multimedia learning environment according to the ADDIE model and students' opinions of the multimedia learning environment. Interactive educational multimedia: IEM, (17), 1-19.

Chiang, C.L. \& Lee, H. (2016). The effect of project-based learning on learning motivation and problem-solving ability of vocational high school students. International Journal of Information and Education Technology, 6(9), 709-712.

Ellis, T. \& Hafner, W. (2008). Building a framework to support project-based collaborative learning experiences in an asynchronous learning network. Interdisciplinary Journal of E-Learning and Learning Objects, 4(1), 167-190.

Gültekin, M. (2007). The effect of project based learning on learning outcomes in the fifthgrade science education. ilkögretim Online, 6(1).

Imaniarta, 1., \& Oktaviana, S. Yahmin. (2013). Pengembangan buku petunjuk praktikum kimia sma berbasis inkuiri terbimbing pada materi laju reaksi dan kesetimbangan kimia. Jurnal Online Universitas Negeri Malang, 2(2), 6.

Manalu, E., Silaban, S., Silaban, R., \& Hutabarat, W. (2016). The development of chemical practice guidebook colloid system-based integrated contextual character values. Jurnal Pendidikan Kimia, 8(2), 8-13.

Meltzer, D.E. (2002). The relationship between mathematics preparation and conceptual learning gains in physics: A possible "hidden variable" in diagnostic pretest scores. American journal of physics, 70(12), 1259-1268.

Rose, R.A., \& Prasetya, A.T. (2015). Keefektifan strategi project based learning berbantuan modul pada hasil belajar kimia siswa. Jurnal Inovasi Pendidikan Kimia, 8(2).

Sepahkar, M., Hendessi, F., \& Nabiollahi, A. (2015). Defining project based learning steps and evaluation method for software engineering students. International Journal of Computer Science and Information Security, 13(10), 48-55.

Syamsu, F.D. (2018). Pengembangan penuntun praktikum ipa berbasis inkuiri terbimbing untuk siswa smp siswa kelas vii semester genap. BlOnatural, 4(2), 13-27.

Tüysüz, C. (2010). The effect of the virtual laboratory on students' achievement and attitude in chemistry. Int Online J Edu Sci, 2(1), 37-53.

Ulger, K. (2018), The effect of problem-based learning on the creative thinking and critical thinking disposition of students in visual arts education. Interdisciplinary J Problem-Based Learning, $12(1)$.

Yance, R.D., Ramli, E., \& Mufit, F. (2013). Pengaruh penerapan model project based learning ( $\mathrm{PBL}$ ) terhadap hasil belajar fisika siswa kelas xi ipa sma negeri 1 batipuh kabupaten tanah datar. Pillar of Physics Education, 1(1), 48-54.

Zulaiha, Z., Hartono, H., \& Ibrahim, A.R. (2014). Pengembangan buku panduan praktikum kimia hidrokarbon berbasis keterampilan proses sains di sma. J. Pen. Pend. Kim, 1(1), 87-93. 